\title{
Another Workplace Is Possible Learning to Own and Changing Subjectivities in American Employee Owned Companies
}

Souleles, Daniel

Document Version

Accepted author manuscript

Published in:

Critique of Anthropology

DOI:

$10.1177 / 0308275 X 19840416$

Publication date:

2020

License

Unspecified

Citation for published version (APA):

Souleles, D. (2020). Another Workplace Is Possible: Learning to Own and Changing Subjectivities in American Employee Owned Companies. Critique of Anthropology, 40(1), 28-48.

https://doi.org/10.1177/0308275X19840416

Link to publication in CBS Research Portal

\section{General rights}

Copyright and moral rights for the publications made accessible in the public portal are retained by the authors and/or other copyright owners and it is a condition of accessing publications that users recognise and abide by the legal requirements associated with these rights.

\section{Take down policy}

If you believe that this document breaches copyright please contact us (research.lib@cbs.dk) providing details, and we will remove access to the work immediately and investigate your claim. 


\section{Another Workplace Is Possible: \\ Learning to Own and Changing Subjectivities in American Employee Owned Companies \\ Daniel Souleles}

Journal article (Accepted manuscript*)

\section{Please cite this article as:}

Souleles, D. (2019). Another Workplace Is Possible: Learning to Own and Changing Subjectivities in American Employee Owned Companies. Critique of Anthropology. 001: 10.1177/0308275K19840416

DOl: https://doi.org/10.1177/0308275K19840416

Copyright (C) The Author(s) २०19. Reprinted by permission of SAGE Publications.

* This version of the article has been accepted for publication and undergone full peer review but has not been through the copyediting, typesetting, pagination and proofreading process, which may lead to differences between this version and the publisher's final version AKA Version of Record.

Uploaded to CBS Research Portal: July 2019 


\title{
Another workplace is possible: Learning to own and changing subjectivities in American employee owned companies
}

\begin{abstract}
Work life in America, as the literature would have it at least, is pretty uniformly miserable. This article will, drawing on literature on practice-based learning as well as democratic political change, show and then theorise a way in which capitalist firms form employee owned trusts (an Employee Stock Ownership Plan or ESOP), and develop an 'ownership culture'. ESOPs with an ownership culture are fairly wide spread, tend to pay people more, and seem to create an environment in which people are happy to work. While ESOPs are not a panacea for all that troubles us, they do seem to go a fair ways towards mitigating some of the work-place-based misery and larger patterns of material inequality that comes with our contemporary moment, and they seem to have been missing from social-scientific thinking about contemporary economic organizing and its possibilities for change.
\end{abstract}

Keywords: Work, Capitalism, United States of America, Ownership, ESOP, Change, Subjectivity

Funding: This work was funded by a Louis O. Kelso Fellowship from the Rutgers University School of Management and Labour Relations.

\section{Workin' 9 to 5, what a way to make a livin'}

Asking the question, 'What's it been like to work for a living, in the United States since the 1970s?' produces a pretty dismal answer. In aggregate, the picture is one of the disappearance of middle-class work, of a slide into poverty for many, and of general, sped-up, workplace immiseration. Greta Krippner (2011), in her book explaining the rise of financialization as a consequence of reactive government policy responses to unemployment and inflation, points out that since the mid-1970s or so, the share of American G.D.P. taken up by manufacturing and FIRE (finance, insurance, and real estate) essentially flipped, with manufacturing going from around $20 \%$ of GDP to a bit above $10 \%$ of GDP, and FIRE going from around $15 \%$ to just over 20\%. FIRE firms, too, generally employ fewer people, and are generally non-union, reflecting the larger employment landscape. These are the sorts of trends that big picture bestseller works of political economy, such as Piketty's (2014) Capital in the Twenty-First Century and Stiglitz's (2013) The Price of Inequality write about, and the sorts of trends captured by statistics such as: 
union participation, which, in 1964 was about $1 / 3^{\text {rd }}$ of all American workers, and is now $1 / 10^{\text {th }}$ (Bui, 2015); the average CEO to lowest paid worker ratio, which, in 1965 was 20:1, and in 2013 was 295.9:1 (Davis and Mishel, 2014); and, of course, the amount of wealth controlled by the wealthiest $1 \%$ of Americans, which, depending on how you calculate it is between $33 \%$ and $42 \%$ of the wealth in America (Lam, 2016). What this all adds up to is that there are increasingly fewer people making more money, and the rest are left behind, doing sparsely-unionised, poorlypaid service work.

This sort of disarray and decay is reflected in ethnographic literature (e.g. Dudley 1994; Bourgeois and Schonberg 2009; Lane 2011; Walley, 2013), is characterized by workplace alienation (Hochsild 1983; Sennett 1998; c.f. Marx 1978), and leads to work that is less stable, less remunerative, harder, and longer (e.g. Fraser, 2002). Standing behind this all is a new class of financiers who increasingly treat companies and the people in them as fungible and ultimately disposable investment vehicles, leading to the speed-ups, lay-offs, and shut-downs that run across the above literature (Ho, 2009; Author, 2017a; e.g Holland, 1989; Burrough and Helyar, 1990; Frasier 2012). This can all be pretty dismal.

Sherry Ortner (2016) has suggested that, mirroring these macro and micro trends in economies and lives, there has been a pervasive "dark" mood within the discipline of anthropology, as researchers have increasingly turned to inventorying and witnessing people on the wrong side of these trends (most people, as it turns out), producing a sort of fatalism or nightmarish determinism in our theoretical outlook. In contrast to this darkness, she suggests that, drawing on Arujun Appadurai, another mode of interacting with the present economic moment, is possible via an "ethics of possibility" which documents possible alternatives, extant though nascent or latent, that may offer some way out of the degradation and misery all around 
us (2016:64-66). What I will suggest, with a bit of qualification, is that we might consider American-based Employee Stock Ownership Plan Companies (ESOPs) as one possible way of reorganizing a capitalist firm to reduce some forms of workplace alienation and societal wealthinequality. Moreover, ESOPs are doubly apt for study because the complicated financial mechanisms that bring them into being are similar to those that financiers use to take over and manipulate other companies for profit, leading to much of the above inventoried misery. Because the same sort of debt-based financing undergirds these dissimilar sorts of take-overs, ESOPs sheer existence demonstrates that contemporary finance need not produce awful ends within a company and that other ways of managing wealth are possible. A bit more broadly, Americanbased firms are particularly good for this sort of work because contemporary forms of finance and corporate capitalism are particularly well-developed there (Pitluck, Mattioli, and Author in press).

ESOPs are companies in which employees own the business in which they work via shares in a trust that in turn owns the underlying company. To be sure, ESOPs are no panacea for all of capitalism's problems (the profit motive remains and they don't do much systematically about environmental degradation), but if you care about people liking what they do for a living, feeling safe, stable, and comfortable in their workplace, and having enough money to retire, ESOPs are instructive.

Given the above general background and gloss of some trends within anthropology, it can be surprising as a fieldworker, researching in the United States to come across a number of companies in which most people are happy with their work, get paid more than in other comparable companies, get laid off less than in other comparable companies, are under less 
managerial supervision than other comparable companies, and, to top it all off, in which employees collectively own where they work. This is what tends to happen in ESOPs (Kruse et al., 2010). In what follows I will describe what ESOPs are and how they work, as well as describe the way in which people learn to be 'owners.'

Within a company, there are a few essential things that need to happen for the aboveenumerated benefits of working in an ESOP to actually emerge. First, employees need to take on the proprietary affect of owners. Further, employees need to change their expectations of how the workplace should work, namely that their opinions and considerations matter to the operation of the company they work in as would befit an owner. In turn, there needs to be changes in how management functions towards employees, such that, rather than common workplace authoritarianism, managers are accountable to worker's demands, opinions, and concerns in some way, again, as befits an owner rather than an employee. Taken together these sorts of shifts and changes in expectation, affect, and political hierarchy are glossed by my informants as what makes up a "culture of ownership," or an “ownership culture.” People learn to be owners. Companies can have an ownership culture. Companies without an ownership culture can learn or grow one. A contribution of this essay, in addition to its particular ethnographic reporting, will be its theorizing and rendering comparable the process of learning by which workers change their subjectivity from 'employees' and 'workers' to that of 'owners,' thereby creating an ownership culture within an ESOP and putting in a necessary condition to accruing the benefits that come with the formation of an ESOP.

I will suggest that, building on theories of democratic organization and psychological subjectivity formation, that practice-based theories of learning help understand how people are drawn into a 'culture of ownership,' and learn how to be owners. Specifically, I suggest that the 
process of "legitimate peripheral participation" (Lave and Wenger 1991; Lave 2011) is a helpful means of understanding how workers become owners, and ESOPs develop ownership cultures. Legitimate peripheral participation suggests that one form of social learning occurs when people come into new social scenes and are slowly integrated by gradually doing the things that makes someone an expert. In this scheme, learning is doing; learning is praxis. Moreover, this mode of explanation works especially well when people are not born into a role they acquire. Further, this mode of praxis based-learning echoes injunctions that social change can, and perhaps should be "prefigurative" (Maeckelbergh 2011; e.g. Reedy, Kind and Coupland 2016). Put glibly, prefiguration is 'being the change', and sees the process by which social change is brought about as every bit as important as an eventual goal. I suggest that for an ownership culture to emerge, one needs to look at how people learn to do day to day business practice and how people act out a shift in values and subjectivity.

Taken one step further, this process of how people learn to own will provide one alternative to how many businesses work and how many people make a living in our current, exploitative and grinding political-economic moment. This alternative, is all the more exciting, because in one degree or another, the process I'll describe is playing out across the nearly 7,000 ESOP companies currently in the United States, which employ around 14,000,000 people (making up about $10 \%$ of the American work force [Bureau of Labour Statistics]), who own assets of around US\$1 trillion (NCEOa, 2015:1). It's worth noting, too, that this is a particularly impressive portion of the US workforce, considering that ESOPs have only been a legal option for company ownership since the mid-1970s (Blasi et al., 2013:159ff) ${ }^{1}$ (cf. Appel, 2015 on 'transformative

\footnotetext{
${ }^{1}$ Right around the time all those other economic trends started to go sideways. It's worth noting further, that ESOPs fit right into the financialization of the American economy as ESOPs create a trust in which employees, through the trust, own shares of the company in which they work. The shares themselves were acquired by an internal leveraged buyout, the same sort of transaction that allowed the private equity industry to take off.
} 
possibility in unanticipated places'). ESOPs too, are one form among many of 'shared capitalism' that runs from $100 \%$ democratically owned worker cooperatives, to large corporations such as Proctor and Gamble or Google granting stock to employees as part of their compensation. Blasi et al., drawing on General Social Survey data states that somewhere around $47 \%$ of workers in the United States have some form of capital or ownership stake in the companies in which they work (2013:112ff.).

Still, it's worth noting again that ESOPs and cultures of ownership don't solve all of our problems. As in the case of the British shareholder-owned company John Lewis Partnership, ESOPs still seek to indefinitely turn a profit, and are still hierarchically run (Paranque 2014:606). Moreover, any amelioration of the situation of workers is reliant on the expansion of ownership and property rights. For this, though, I feel if we were to write-off ESOPs as insufficiently alternative, we would be misguided. We shouldn't necessarily be looking for some form of universal deliverance from capitalism writ large, anyway. Parker, Cheney, Fournier, and Land observe in their Companion to Alternative Organization (2014) that, "in reality, capitalism is partial and fragmented," (19), and consequently, "not all alternatives are 'against' everything, or 'against' the same things." (364). ESOPs aren't interesting because they are a solution to all of our problems, or to some hegemonic, capitalist social gravity, rather they solve particular problems with the way work life currently works. Insofar as we theorize contemporary economic arrangements (which we often gloss as "capitalism") as leading to knowable and predictable harms (workplace alienation, material inequality, environmental degradation, indifference to and the sacrifice of particularly long-standing groups of people, and so on), any sort of alternatives we investigate likely won't solve all the problems we see. ESOPs are no different in this regard, though there are a lot of them, and they do make life better for a lot of people that work in them. 


\section{The Research Plan}

I note the ESOP timeline above, as their rise runs parallel to the emergence of another economic phenomenon, that of Private Equity (Author, 2017b). Private equity emerged in the late 1970s, and early 1980s as an industry and a strategy that used debt to buy companies relatively cheaply, put that debt on the bought company, and then treat the company like an investment, pulling wealth out of the company, getting out in a few years and distributing profit to investors and financiers (Appelbaum and Batt, 2014). As noted above, this attitude towards work and business, treating companies as investments, and people as disposable has led to a nasty working world in many ways. From late Spring of 2012 to late Summer of 2014 I was studying private equity investors, trying to understand why and how they bought, managed, and sold companies. Towards the end of this research, I came across a private equity firm that was creating ESOPs as a way to cash out of their investments. This struck me as unusual—private equity firms are not typically in the habit of selling companies to employees. But from their point of view it made sense- - you borrow money to do a leveraged private equity transaction, similarly, you can borrow money to create an ESOP (the tax benefits were also pretty good). However, when you create an ESOP the people to whom you're selling the company are neither other investors, nor a larger corporation making a strategic acquisition (think Google buying youtube), nor are they anonymous buyers on a stock exchange (say, facebook having an IPO). When private equity sells to an ESOP they're using debt to cash themselves out and transfer the ownership (and debt) of a company to an ESOP trust and, in turn, workers in the company. It's the same leveraged-financing mechanism PE investors use in whatever they do; in this case, though, it leads to the creation of an employee owned company. Similarly, whenever owners sell a company to their employees to create an ESOP, they use this sort of debt-based financing that 
was pioneered with private equity. The rise of finance created the mechanism that allowed for private equity; but that same mechanism of wealth allocation and debt can be put to other ends.

That said, I should be clear that ESOPs are not necessarily democracies in the way that a worker-owned cooperative would organise things. In a worker-owned cooperative, workers have direct democratic control over the company (for a general introduction to cooperatives and communalism in American history see Curl, 2009; see also Parker, Cheney, Fournier, and Land's 2014 Companion to Alternative Organisation).

In ESOPs, by contrast, the conventional governing mechanisms of a corporation are maintained - a board selects an executive, an executive hires management, and management hires workers and runs the workplace. Where things differ with an ESOP is that the board is selected and often dominated by an ESOP trustee who is able to vote whatever percent of shares the employees own in their ESOP trust (so, in a 100\% ESOP, the ESOP trustee has $100 \%$ of the votes), according to the legal fiduciary standards of whatever American state the business happens to be incorporated in. Given that this is the bare minimum requirement for ESOP governance, in actuality there is a broad spectrum of ESOP governance that, again, run the spectrum from democratic control of budgeting and executive selection, to conventional American workplace authoritarianism, albeit with higher pay. Most companies are somewhere between these two poles. All this is to say, it was surprising to find ESOPs emerging from private equity transactions. Private equity investors are using the tools of leveraged finance to turn workers into owners (cf. Hart, 2015 on 'the real task' of how 'big money...might be selectively combined with citizen's initiatives to promote a more democratic world'[5]).

At the time of my private equity study, private equity controlled about US\$3.5 trillion in assets and had invested about US\$2.5 trillion of that in companies (Fogarty, 2014), only about 
2.5 times more assets than are owned by ESOP trusts. Given how strange this all sounded, and given that I'd never heard of an ESOP ${ }^{2}$, I set about, from February of 2015 through February of 2017, on a study of how and why ESOPs with ownership cultures are created. Again, the degree to which an ESOP has an ownership culture, or even majority employee share ownership is variable.

Given that, and given the role that other literature seemed to suggest an ownership culture played in all the workplace benefits of an ESOP (more below), I elected to learn about majority employee-owned ESOPs that explicitly claimed an ownership culture. To answer this question, I conducted 88 life-history and ethnographic interviews with 76 informants, around a third of which drew broadly across the ESOP universe (workers in ESOP companies, management in ESOP companies, lawyers, consultants, lobbyists, etc.). $2 / 3^{\text {rd }}$ of the interviews, in turn, were across three companies that worked with each-other to create an ESOP: a financial valuation firm, an organisational consulting firm, and an ESOP engineering consulting firm ('Sapphire Solutions'). Sapphire was an ESOP that maintained a conventional hierarchical business structure (board, ceo, managers, workers) with a few important caveats - it shared all financial information with employees, it had regular processes in place by which management solicited criticism from employees, employees controlled the social culture of the firm through social and charitable activity, and, of course, employees, through a trustee, owned the firm (more on all of this below). I also conducted limited observation work over six weeks in total across each of the three firms which saw me going to Philadelphia for the consultants, a small Southern Town ('ST') for the engineers, and New York, Chicago, Cleveland, and the suburbs of Washington D.C. for the financiers. I also attended 5 ESOP conferences and accumulated an archive of

\footnotetext{
${ }^{2}$ It wasn't just me! ESOPs are rarely taught in business or law schools, and the few non-ESOP-specialist finance people that I knew who had heard of ESOPs thought they were weird, uncommon, and not worth their time. The scholars of ESOPs, too, such as Blasi and Kruse, cited throughout this paper, are housed in labor relations schools.
} 
printed materials from each firm. All told, this is more or less the pattern of study for a multisited ethnography (Marcus, 1995), that involves studying up (Nader, 1972; Gusterson, 1997), and is concerned with a social process that spans numerous particular social sites (e.g. West, [2012] tracing out the commodification of coffee from Papua New Guinea), in this case, how one creates an employee owned firm with an ownership culture.

One further prefatory note: despite my past ignorance of ESOPs, and as noted above, there has been a considerable amount of aggregate scholarship done on how ESOPs tend to perform (e.g. Kruse et al. 2010 reporting on survey research in conjunction with the National Bureau of Economic Research [NBER]): from the effects of worker ownership on productivity (goes up), shirking (not as much of an issue as you'd think), and the generation of wealth (this seems to happen); we have good reason to believe the NBER survey reported on by Kruse et al. (2010; cf. Blasi, Kruse and Bernstein 2003) paints a reasonably clear picture, albeit in aggregate, of employee owned firms. However, some of the study authors observe that despite, 'shared capitalism, employee involvement, and other positive labour factors...[being] complementary...[they may] operate through a latent variable, 'corporate culture' (Freeman et al., 2010:22). In addition to contributing to the general anthropology literature on work in the United States, as well as that on political and subjective change, the following analysis should go some way towards demystifying the 'latent variable of corporate culture.,' by way of explaining more about how an ownership culture forms. This is helpful, again, because an ownership culture seems to be the bridge to an ESOP's benefits.

To do so, over the remainder of the paper, I will explain the steps and stages by which workers at Sapphire Solutions become employee owners. Again, I suggest that employees gradually come into the community of ownership (cf. a 'community of practice,' as in Lave and 
Wenger, 1991 and Lave 2011) and become familiar with what they can reasonably expect of the company (a voice in the operation and management of the company, stable work, and ownership shares), and what the company expects of them (enthusiasm, loyalty, and extra work), by explicit education, company events and meetings, as well as a general discursive style that frames correct actions in terms of ownership. All this works, too, due to explicit comparison of how things work at Sapphire to the perceived nightmare that awaits one working at other companies. So, without further stalling and signposting, onward to the ballad of Perry Placid, a Senior Design Engineer at Sapphire Solutions who gives some sense of what ownership looks and feels like.

\section{'Ten Years Later I Couldn't Make a Better Decision'}

Perry Placid is a Senior Design Engineer at Sapphire Solutions, again, an engineering contract services firm based in ST that does defense and aerospace contracting. Perry is your typical employee of Sapphire. He's in the middle of his career. He's from the South. He's trained as an engineer, and practicing his trade.

ST is home to a large federal military installation that houses a number of government agencies - people that do everything from missile defense to NASA work. Practically speaking, for working engineers, this means that in addition to a few dozen military and government agencies that employ engineers, there are hundreds of contracting and subcontracting firms, leading numerous of my informants to brag about the concentration of PhDs (perhaps the highest in the country!) in little old ST. To give some sense of things, when I worked with Sapphire, they employed around 1000 employees, about 600 of whom were in the area. They, in turn, invoiced around 120 subcontracting companies per month. So, there are a lot of place for engineers to work. In addition, much of the work is contract-based, meaning that engineering firms will bid on government contracts (for say, a system that can render and freezeframe a missile explosion 
with augmented reality headsets for close analysis), and, if they win the contracts do the work over a fixed period of time. This leads to a situation in which work can be tempestuous. If your company loses your contract or has no work for you, you are often fired. Couple this with the fact that many engineers work away from corporate headquarters in government labs, there can be a sense of disconnect with the people you ultimately work for. All told, consulting is generally contingent, relatively short-term, and, possibly volatile. Engineers will frequently hop from firm to firm as the vagaries of contract fortunes shift.

After completing an undergraduate degree in computer science, and working a number of co$\mathrm{op}^{3}$ positions in power companies in the Southeastern United States, Perry found his way to a job at NASA (the American 'National Aeronautics and Space Administration' responsible for, among other things, spaceflight). He ended up working at NASA for around 7 years, and completed a Masters in his field over that time. A lot of the programs he was working on or supervising at NASA were largely being completed by outside contractors in the form of smaller entrepreneurial companies in and around ST. From these companies and his friends therein, Perry remembers getting a sense that the government was not necessarily the place to work. He gradually came to see working inside a government agency as more or less 'low motivation,' and lacking in 'opportunities to do something exciting.' He gradually came to see that 'something exciting' as being, 'not necessarily [related to the] space program, [but the opportunity to] grow in a company.' So, Perry left NASA and bounced around for a few years.

He worked in a string of smaller entrepreneurial government contracting companies. But, he observed that things hadn't changed as much as he would have liked. He cycled through contracting companies as well as tech start-ups, and ultimately churned out of all of them. None

\footnotetext{
${ }^{3}$ Engineering schools often have semester long stretches of work that break up college years and are a formal part of education and training. These programs are called co-ops.
} 
of them were particularly successful and some had resorted to abusive managerial strategies such as reducing the amount of people employed as a cost-saving exercise and expecting the same amount of work to get done. Finally, nearing 40, and as the start-up he was currently working for had just sold, he started thinking that he'd have to reconsider his career goals. And, as luck would have it, it was about this point that he heard about Sapphire Solutions.

Sapphire, by this point, was three years old. He heard too about how they were working towards $100 \%$ employee ownership ${ }^{4}$. While a bit apprehensive, as he wasn't sure what to make of a $100 \%$ employee owned company, to him, 'this one seemed legit.' Perry noted that he felt 'confident' in the 'motivation' of the people working at the firm. Still, he struggled with the decisions. While people did seem motivated, and he did like the sound of the job that would allow him to continue working in his engineering specialty, the novelty of joining an ESOP gave him pause. Eventually, though, he took the plunge and, '10 years later,' he feels that he, 'couldn't make a better decision.' When I asked him why that was, he explained that as an owner, 'You control how successful or not the company is.' It may be a, 'small part for each person, but collectively you're working for yourself.' He understands Sapphire as, 'owned by employees; we decide what happens to the company.' He saw all this in explicit contrast to the string of smaller start-ups he worked in that were led by charismatic entrepreneurs who eventually cashed-out, leaving most everyone else behind. In Perry's estimation, ESOP trust ownership of the company provides the ultimate assurance that this won't happen. In his understanding of things, if someone wants to buy the company, '[the] owners have to vote...everyone has a say' (c.f. Paranque 606)

\footnotetext{
${ }^{4}$ ESOP conversion rarely happens in one go. It usually takes several rounds of financing to buy out original owners and stock holders and build the ESOP trust.
} 
Perry sees a direct connection between people's work and the growth of the Sapphire. He has been vindicated in his sense of things too, since Sapphire has grown to a thousand-person company in a bit over a decade. Too, the value of Sapphire, as determined in a yearly financial valuation for the purposes of setting a stock price and quantifying the worth of employee's ownership stakes, has doubled a few times over. Not only is Perry an owner, but he feels like one and he feels that employees steer the direction of Sapphire. It's worth pointing out that this loyalty and enthusiasm is not a necessary accompaniment of the mere fact of ownership. Moreover, were Saphire's situation to change, Perry would by symmetrically poorer. Though, Sapphire and many other ESOPs offer additional retirement savings (such as an employer matching 401k) to blunt this risk.

Another informant, Liz Lightfoot, working at an employee-owned consulting firm, also with around 1000 employees, who made use of the same financial adviser at Sapphire, had a different sense of things. She said that, yes, they do get an annual valuation explaining the worth of their shares in the company, but she gets, 'a kick out of this.' It comes every year with an explanation of her total compensation package and she doesn't, 'really understand what it means. It's like monopoly money.' Liz didn't understand how the ESOP governance structure worked, how employees managed their trustee. She thought, in a vague way that it might affect her retirement. She said too, that employees would bring up the fact of their 'ownership' of the company when management did things with which they did not agree (such as spending money publishing annual glossy compensation dossiers explaining how much everyone is getting paid). A more salient way of understanding her and her colleagues work, was that it was 'mission driven,' and that they all were committed to researching and helping people. Insofar as the consultancy was 
ESOP and employee owned, it all basically seemed like 'internal PR,' and, 'a lot of noise' (c.f. Heras-Saizarbitoria 2014).

Both Liz and Perry work in similarly sized ESOP companies that make money by doing consulting work. And yet, their apprehension of their respective work-places is worlds apart. Liz is cynical about the ESOP, not really understanding it, and writing it off as managerial propaganda. Insofar as it rises to the level of discourse, it's more or less in the form of impotent complaint or ironic commentary. By contrast, Perry has a bone-deep feeling that he and his colleagues own and are responsible for Sapphire. He clearly sees increases in Sapphires value as directly related to his and his colleagues' effort and planning. As I talked to Perry, I tried to figure out what it was that distinguished Sapphire from Liz's firm. It seemed that it was that latent variable 'culture,' specifically, how people came into and were taught to understand Sapphire. Perry talked about a committee of employees, an ESOP communication committee, which produced brochures and lead training for new hires. He also talked about other aspects of company 'culture', such as charitable work that employees collectively did, learning about company history (even at just a decade old!), education about understanding how valuation works, and a sequence of other events, trainings, and meetings that all added up to Perry's sense of ownership.

Part of the reason I am dwelling on the distinction between Liz's and Perry's ESOP workplace is, again, as noted above, there is some suggestion that the gains in productivity, job stability, pay, and profit that accrue to ESOPs act through the 'latent variable' of company culture - that is how people understand and learn to be owners, then act on that understanding. What Perry and Liz illustrate is that ownership is not simply conferred at the transfer of stock. Owning a company doesn't make you an owner. You have to learn to be an owner and your 
company has to have structures in place that support workers taking an active role in managing their own business. To appreciate how all this works, it will help to take a quick detour into theories of learning and theories of political and economic subjectivity formation.

\section{Learning to Own}

In another essay on trends in anthropological theorizing, Ortner (1984) observed that theorizing in anthropology since the 1960s had been marked by a turn toward processual and practice-based accounts of social life. That is, instead of trying to fit people's lives into older, fixed, static, and schematic intellectual theories (such as cultural ecology or structuralism), anthropologists turned towards the sequences and the processes of being and becoming (as in, how does someone become an owner). One such theoretical gambit is Gene Lave and Etienne Wenger's (1991; see also Lave, 2011) ‘legitimate peripheral participation’ in which:

Learning [is] viewed as situated activity[, and] has as its central defining characteristic a process that we call legitimate peripheral participation. By this we mean to draw attention to the point that learners inevitably participate in communities of practitioners and that the mastery of knowledge and skills requires newcomers to move toward full participation in the sociocultural practices of a community. [29]

They note too, of this theory of learning, that, 'Legitimate peripheral participation is intended as a conceptual bridge - as a claim about the common processes inherent in the production of changing persons and changing communities of practice' (55-56). What I suggest is that an employee like Perry in a company like Sapphire, as opposed to an employee like Liz, in her consulting firm, proceeds through a series of steps and stages by which that employee like Perry is taught how to be an owner: how to act like an owner, think like an owner, and do the things that employee-owners do. Lave and Wenger use skilled trades, tangible tasks, and apprenticeships for a number of their examples, everything from midwifery, to tailoring, to meat cutting. But they also suggest that people can, not so much learn a specific skill, but come to 
adopt an abstract schema to understand their lives, as in the case of a nondrinking alcoholic interpreting their past (84). And it is this aspect of legitimate peripheral participation that I suggest makes someone an owner, not so much learning a skill (though there is some of this in some of the activities that owners undertake, such as understanding financial reports), but acquiring a schema (Holland and Quinn, 1987; Holland et al., 2001) by which to interpret work life and the condition of owning a share of a company (for what can happen in the absence or routinization of such training and processes, see Heras-Saizarbitoria 2014)

It's worth noting, too, that this notion of participating your way into a new schema, of individuals learning to be more democratic or more economically self-sufficient, is attested to ethnographically. David Graeber (2009), in writing about the New York-based Direct Action Network (DAN) and their protests, politics, and actions as part of the global justice movement, notes that anarchist activists embrace a 'prefigurative' notion of political action (again, see Maeckelbergh 2011; see also: Graeber 2014), believing that their protest should mirror (prefigure, or demonstrate) their directly democratic politics. The meeting and organization is just as ethically important as ultimate political action. In practice, this means a lot of talking and a lot of consensus seeking. In turn, what DAN and other anarchists presume happens to someone who spends any amount of time in this context is a sort of learning by osmosis or, a 'contaminationist' [sensibility]. The assumption is that direct action and direct democracy are infectious; almost anyone exposed to them is likely to be transformed by the experience' (28). I think there is a lot of truth in this. Informants I've met have noted how exhilarated they felt by ownership cultures. But the simple act of exposure to stock certificates as Liz points out, and as prefigurative politics would suggest, isn't quite enough. There have to be participatory, educative stages through which people progress to become owners. 
Gibson-Graham (2006) in their Postcapitalist Politics, write about the way in which people living in locations in economic decline or on the periphery of more prosperous economic systems, the Latrobe Valley in Victoria, Australia, the Connecticut River Valley in the U.S.A, and an agricultural community of the Jagna Municipality in the Southeastern Phillipines, are able to move into new subjectivities, or understandings of what they are capable of as people, despite coming of age in an economic order that no longer exists. Following insights from Lacanian psychoanalysis, they design a series of action research projects that, 'interrupt the analysand's project of shoring up her fantasies, which lock her into fixed structures of desire and identity [how economically depressed people are meant to see themselves as useless and atomized]. An interruption by the analyst can provoke the analysand's curiosity and begin the exploration that unravels fantasy and reveals it for what it is [or, can help people see that other worlds and roles for themselves are possible]' (129). Gibson-Graham facilitate projects that look like community inventories in which people try to see themselves, their neighbors, and their region as resourceful and connected, thereby bringing a new world into being (144). Again, there is much of use here. Gibson-Graham emphasize the processual nature of coming into a new schema and thereby a new community of practice, using the metaphor of a particular type of psychoanalytic intervention. What makes ownership culture in an ESOP particularly interesting though is that it does not happen in a place of decline or on the margins, and it doesn't happen in a new political movement. It happens in the context of a typically quietist business setting.

Now that we've seen the difference between Liz and Perrry's experience of ownership; now that we have a sense of what it means to see learning as a process of legitimate peripheral participation by which an individual comes into a community by gradually learning how to do the things that that community does; now that we've seen the legitimate peripheral participation 
can describe someone's acquisition of a new subjectivity and schema; and now that we've seen some other examples of shifts in economic and political subjectivity, it's worthwhile to inventory what exactly happens at Sapphire Solutions to make people feel like owners. To do so I'll walk through an example of introductory activities people do when they become employees and learn to be owners, a few examples of reoccurring activities that people do when they become employee owners, and a story that will give a sense for how management is shifting in the context of employee ownership.

\section{Ownership as Bildungsroman}

\section{An Introduction from the ESOP Ownership Committee}

At Sapphire, like many other ESOP companies, the Employee Ownership Communications Committee (EOCC) introduces the company to the new employee, and initiates the employee into the context of employee ownership. EOCCs are generally all-volunteer committees of non-managerial employees who are responsible for ESOP education, and fostering an ownership culture. At Sapphire, shortly after conversion to a 100\%r ESOP, about 7 years ago, a senior-VP, who one employee described as 'touchy feely' about ownership, asked a number of employees if they were interested in starting an $\mathrm{EOCC}^{5}$. One of those employees was Wren Reynolds, a lead engineer. Wren said that he was eager to join the committee because he wanted to have a hand in crafting the committee's mission which was to share the sentiment that, 'the mission to establish and ownership culture [was to] share in the gains,' of the company, and in turn, 'foster an ownership culture.' Around that mission, the EOCC has set up a number of recurring events.

\footnotetext{
${ }^{5}$ Prior to the founding of the EOCC, culture education for new hires was done by the CEO. The shift to a committee happened as Sapphire grew, and senior leadership wanted a sustainable way to teach the culture. And thus charisma is routinised.
} 
First, after employees arrive at Sapphire, they are periodically given an orientation in which fellow employees explain how an ESOP works and how to understand the relationship between Sapphire's annual valuation and an individual employee's accumulated wealth. In tandem with this, Sapphire has produced several hours of company history, explaining the origin of the idea to make Sapphire an ESOP. Briefly, a number of senior managers in the late 1980s and through the 1990s worked in a defense contractor that was ultimately bought out. In the wake of that buyout people were treated badly to such an extent that most people who worked at the company quit and scattered. Sapphire's early management had a sense of a sort of paradise lost, and wanted to design a business where employees shared in wealth and in which there was no danger of being bought out. In turn, the several hours of company history underscore several concrete steps that management has taken to create a structure that shield employees from a buyout, such as establishing the ESOP, encouraging cooperation in seeking new government contracts, and demonstrating a commitment to not fire or lay people off in the event of difficulty getting contracts. Moreover, the history also highlights a series of times that management has allowed relatively junior people the opportunity to pursue risks for Sapphire or enjoy opportunities for growth, such as pursuing particular contracts or opening satellite offices around other military installations with relatively little supervision.

The EOCC's peer-lead initiation, coupled with the program of viewing Sapphire's history inundates new hires with the language of ownership, extra responsibility, and suggests that all this is essential to working at Sapphire. Moreover, new hires begin to pick up a way of talking about themselves, not as workers, but as owners, that allows them to participate in the ongoing rituals of ownership that delineate Sapphire's year.

\section{Charity, Guessing the Stock Price and the All-Hands Meetings}


One of the events that marks time at Sapphire, is the all-hands meeting. Coming several times-a-year, and generally scheduled to coincide with major company news, the all-hands meeting brings together as many employees of the company as possible to hear from senior management. At these meetings, senior managers will go over the basic financial health of the company, and new contracts or new offices added, an explanation of the health of the ESOP plan, as well as numerous employee endeavors such as social events and employee led charitable giving. The financial health of the company is particularly important to an ownership culture as it encourages employees to have a big picture sense of what contributes to the company's wealth and how employees, individually help those actions. Moreover, too, every year in the lead up to the company's annual valuation, the EOCC leads a guess the stock price competition among employees. In addition to the regular update on Sapphire's financial health, employees have access to company financial documents via a company-wide intranet, which allows them to check on things like cash flow and profitability.

Beyond the financial health of the company, a representative from the EOCC will discuss ongoing events-holiday parties, company picnics, as well as employee sponsored charitable giving through a program called 'Sapphire Aides.' Sapphire Aides is an independent non-profit organization run by Sapphire employees that collects voluntary donations from employees, solicits grant applications from local charities, and then collectively chooses which applications to send donations to. Since 2005, Sapphire Aides has given out nearly US\$700,000 in US $\$ 10,000$ grants to organizations like local food banks, church charities, and habitat for humanity. Most of the employees I spoke with brought up Sapphire Aides and said how different it felt from the charitable opportunities at other companies which may have been a limited 
individual matching employee donation or the occasional field day in which employees help out on projects around town (which, incidentally, Sapphire also does).

\section{Management on Notice}

One of Liz's complaints about her ESOP-without-an-ownership-culture was that she felt like all the talk of ownership was just internal propaganda. To this point in the article, it's possible too that an uncharitable reader might accuse me and Sapphire of the same thing. After all, sure, employees are getting a bit more money, and it seems more difficult to sell the company, but most of what I've listed could be written off as framing devices and superfluous information. It doesn't much matter if you know about a company's financials if you can still get fired and if management and ownership isn't democratically controlled, one person, one vote. There is something to this, in that it does point out that there is not a flat consensus-driven decision-making process as with Graeber's depiction of the Direct Action Network. But, the structure of management is also not quite as hierarchical as one would expect in a normal company. Put another way, the norms of ownership significantly limit the scope of acceptable managerial action, to the point that managers not embodying a collegial, solicitous attitude towards subordinates are disciplined and may ultimately be asked to leave. An untoward exchange I witnessed in a meeting will illustrate what I mean.

At one point in my Sapphire field work, I was able to sit in on a meeting in which different business units were reporting on how things were going with their own contracts, and what they foresaw as opportunities and perils in the coming year. Coraline Carper, a Directorate Manager, was giving her presentation and towards the end of it she noted that the current presidential administration was proposing significant increases in defense spending which would be good for her business unit. Then, Coraline was abruptly cut off by Siegfried Seaweed, another 
member of senior management. Siegfried interrupted Coraline saying that, 'she should look at the constitution.' Coraline was confused. Siegfried said that the budget comes from the congress, not the president, effectively breaking the flow of Coraline's presentation and leading to a sequence of awkward back-and-forths in which Coraline insisted she was aware of the constitution and how the federal government of the United States worked.

I suspect many people reading this will not necessarily be surprised with this exchange. In an open collegial setting, a male co-worker directly shuts down a female coworker. Of course, Coraline knows about how congressional budgeting works; as a defense contractor that's her job. But, unlike in other companies, this exchange was not the end of things.

A day or so later, I was driving around with another senior manager, Casper Crux. We were chatting and he asked me, 'if there was anyone at the company that it struck me was fragile in the culture?' I laughed and said that Casper probably knew the answer. I told him that there was only one person I'd met who saw fit to bring up the constitution when discussing budgeting. Casper sighed, and told me that he was confounded. On the one hand, Siegfried brought a lot to the table: he had a lot of experience and had deep knowledge of defense contracting. Also, when he talked to Siegfried, Casper got the sense that he really cares about people. To this point, Siegfried had even taken the time and care before my field trip to look up and read my own work, and talk to me a bit about it when I met him. But this all seemed different from a public persona Siegfried sometimes had, which to me at least could seem brusque or even dismissive. Casper reflected that Coraline contributed a lot to company employee-ownership activities in addition to running a very successful directorate. The buzz was that she was on her way up for a promotion. 
Casper was frustrated. He noted that in the past, he had suggested that Siegfried should get some executive coaching, that is, one on one counseling with an organizational psychologist to help Siegfried fit in better with the collegial ownership culture. But, Siegfried was not interested in coaching. I asked Casper why, and he said that he didn't know. Casper went on to say that a few years ago he himself had gotten coaching. It came up in a 360 review, that is, a mostly anonymous review completed by one's sub- and super-ordinates, that Casper tended to be domineering in meetings. Casper said that he loved the coaching, and that it helped him listen more to people, and open up space in meetings for everyone to talk and contribute to problem solving. He said that for a long time he felt like he had to get his ideas out as soon as he had them in meetings, but now he appreciates the fact that other people often have similar notions of things and that there is a lot of benefit in listening and acting cautiously. Too, to his credit, Casper did now seem to have a preternatural equanimity in meetings and discussions. As Casper and I talked more about the vagaries of staffing, management, and trying to maintain Sapphire's ownership culture, it seemed, to me at least, that somewhere down the line, Siegfried, if he didn't figure out a way to be nice in group contexts, might find himself on the way out of the organization.

I draw attention to this turn of events because, given how social scientists commonly understand the American workplace, and the boss-worker relationship, this is unusual. Robert Jackall (1988), in his book Moral Mazes, The World of Corporate Managers, describes the prevailing mode of American management as, 'patrimonial bureaucracy,' a system, 'marked by patronage and by intrigues and conspiracies to gain the favor of the ruler and the perquisites that accompany his good grace' (11). Too, this is what I've observed in most non-ownership-focused firms I've observed across my various stints of fieldwork. But, this is not what is happening in the case of Siegfried Seaweed at Sapphire. Here, instead, other managers are intervening on 
Coraline's, and presumably other worker's, behalf, not to score narrow political points or gather resources, but in order to act in favor of the norms of an ownership culture (cf. Mahony, 2006 on 'value rationality'), one in which the opinions and dignity of an employee owner are paramount.

\section{Another Workplace is Possible}

About a year before my field trip to Sapphire, I did interview work and observational work at the organizational consulting firm from which Casper received his coaching. In fact, I was able to talk with his coach, Louise Linden and elicit her philosophy in working with ESOP companies and their managers, as she helped people like Casper mellow out and empower the people in his company. Louise says she started from a premise of, 'social economic justice,' and that she thinks, 'About what creates poverty in the United States, [and] globally, and... what is the relationship between capitalism and economic systems in which there is a permanent underclass, and [how] that gets reified with issues of race and gender, sexual orientation.' Working on ameliorating these issues has been her priority in her adult life. So, 'the appeal around ESOPs [has to do with] there [being] ways within a US capitalist framework that you can have structures in which workers are able to reap more of the profits that come from their labour, [ways of seeking] economic justice.' Tangibly, this means helping ESOPs work better and encouraging ownership cultures. On a day to day basis, Louise takes someone like Casper, and tries to get him to see, 'the multiple identities [he] bring[s] to work,' as well as, 'what barriers [there are] for people [like him] at an interpersonal level,' all so that the manager or executive can better, 'achieve the mission of [their] organization,' which in Casper's case is to broadly share in the success of a business well-run by means of nurturing an ownership culture.

Towards the start of this essay I suggested that one of the exciting things about ESOPs was that there were so many of them already, and that many of them are developing ownership 
cultures which shift the social sense of a business away from 'sociopathic capitalistic competition,' to paraphrase one of Sapphire's executives, and moving toward a cultural logic of more broadly shared prosperity refracted through the schema of ownership (cf. Tsing, 2015 on what emerges from ruins; Bear, Ho, Tsing, and Yanagisako 2015 on the generative possibilities of capitalism). It was my hope, too that this paper would prove a worthy contribution to the social scientific literature on work in America by illuminating how employees learn to be owners, as one alternative way of structuring work-life that ameliorates some of the depredations we generally associate with capitalism. Insofar as a there is a larger theoretical point to be made, it's one that echoes Tsing, Bear, Ho and Yanagisako, and suggests that the dark mood that Ortner observed in anthropology and that stretches across much of how social analysts think about contemporary life and work need not be deterministic. ESOPs shows another way that debtbased financial capitalism has unfolded, an alternative. It's not full on utopic communalism (people still yell at eachother, folks still look for a profit), but it's also not entirely authoritarian capitalism. It's a new social formation that often leaves people feeling very good about the work they do, and getting paid more to boot. It's not the millennium; but it's also quite a bit better than many other jobs out there. In closing, rather than offer more winged words and ponderous platitudes, I'll offer up a chart. Figure 1, below shows, as of 2015, the company, location, industry, and number of employees of the 20 largest ESOP companies in the United States ${ }^{6}$. I do this to illustrate that not only is another world possible but, in part at least, it's already here if you know where to look for it.

\begin{tabular}{|l|l|l|l|}
\hline Company & Location & Business & Employees \\
\hline
\end{tabular}

\footnotetext{
${ }^{6}$ National Center for Employee Ownership 2015b. The chart I created is drawn from a larger chart that the NCEO published which lists America's 100 largest Employee-Owned Companies. I have only listed the top 20 companies that were exclusively ESOP companies. Some other forms of employee ownership that they list are 'profit sharing,' 'stock purchase plan,' and 'stock incentive plan.'
} 


\begin{tabular}{|c|c|c|c|}
\hline Publix Super Markets & Lakeland, FL & Supermarkets & 175,000 \\
\hline Daymon Worldwide & Stamford, CT & Food Distribution & 39,000 \\
\hline Lifetouch* & Eden Prairie, MN & Photography & 25,000 \\
\hline Houchens Industries* & Bowling Green, KY & $\begin{array}{l}\text { Supermarkets \& other } \\
\text { services }\end{array}$ & 18,000 \\
\hline Penmac* & Springfield, MO & Staffing & 17,000 \\
\hline Amsted Industries* & Chicago, IL & Industrial Components & 16,800 \\
\hline Parsons* & Pasadena, CA & $\begin{array}{l}\text { Engineering \& } \\
\text { Construction }\end{array}$ & 15,000 \\
\hline WinCo Foods & Boise, ID & Supermarkets & 15,000 \\
\hline Alliance Holdings* & Abington, PA & Holding Company & 14,670 \\
\hline Black \& Veatch & Overland Park, KS & Engineering & 10,285 \\
\hline $\begin{array}{l}\text { W.L. Gore \& } \\
\text { Associates }\end{array}$ & Newark, DE & Manufacturing & 10,000 \\
\hline HDR, Inc. & Omaha, NE & $\begin{array}{l}\text { Architecture \& } \\
\text { Engineering }\end{array}$ & 9200 \\
\hline $\begin{array}{l}\text { The Burnett } \\
\text { Companies } \\
\text { Consolidated, Inc.* }\end{array}$ & Houston, TX & Staffing Services & 7040 \\
\hline Brookshire Brothers* & Lufkin, TX & Supermarkets & 7000 \\
\hline MWH Global & Broomfield, $\mathrm{CO}$ & $\begin{array}{l}\text { Engineering \& } \\
\text { Consulting }\end{array}$ & 7000 \\
\hline Schreiber Foods & Greenbay, WI & Dairy Company & 7000 \\
\hline
\end{tabular}




\begin{tabular}{|l|l|l|l|}
\hline Austin Industries* & Dallas, TX & Construction & 6500 \\
\hline Sterling Global & Lenoir City, TN & Security \& Munitions & 5500 \\
\hline Rosendin Electric* & San Jose, CA & Services & \\
\hline Blue Tee & New York, NY & Industrial Machinery & 5000 \\
Corporation* & & Distribution & \\
\hline
\end{tabular}

Figure 1: 20 Largest majority employee-owned ESOPs. *Indicates 100\% employee-owned.

Post Script: As I revised this article, I learned that Coraline had in fact been promoted to Senior Manager.

\section{References}

Appel, Hannah (2015) Occupy Wall Street and the Economic Imagination. Cultural Anthropology 29(4):602-625.

Appelbaum, Eileen and Rosemary Batt. (2015) Private Equity at Work: When Wall Street Manages Main Street. New York: Russell Sage Foundation.

Author (2017a) Don't mix Paxil, Viagra, and Xanax: What financiers' jokes say about inequality. Economic Anthropology 4:107-119.

Author. (2017b) Something new: value and change in finance. Journal of Cultural Economy 10(4):393-404.

Bear, Laura, Karen Ho, Anna Tsing, and Sylvia Yanagisako (2015) 'Gens: A Feminist Manifesto for the Study of Capitalism.' Cultural Anthropology website, March 30.

https://culanth.org/fieldsights/652-gens-a-feminist-manifesto-for-the-study-of-capitalism.

Blasi, Joseph R., Richard B Freeman and Douglas L. Kruse (2013) The Citizen's Share. New Haven: Yale.

Blasi, Joseph, Douglas Kruse, and Aaron Bernstein. (2003) In the Company of Owners: The Truth About Stock Options. New York: Basic Books.

Bourgois, Philippe and Jeff Schonberg (2009) Righteous Dopefiend. Berkeley: University of California Press. 
Bui, Quoctrung (2015) 50 Years of Shrinking Union Membership, in One Map. NPR: Planet Money February 23. http://www.npr.org/sections/money/2015/02/23/385843576/50-years-ofshrinking-union-membership-in-one-map. Accessed June 9, 2017.

Bureau of Labor Statistics (n.d.) Labor Force Statistics from the Current Population Survey. http://data.bls.gov/pdq/SurveyOutputServlet?request_action=wh\&graph_name=LN_cpsbref1 . Accessed November 7, 2015.

Burrough, Bryan and John Helyar (1990) Barbarians at the Gate: The Fall of RJR Nabisco. New York: Harper Collins

Curl, John (2009) For All the People: Uncovering the Hidden History of Cooperation, Cooperative Movements, and Communalism in America. Oakland: PM Press.

Davis, Alyssa and Lawrence Mishel (2014) CEO Pay Continues to Rise as Typical Workers are paid Less. Economic Policy Institute, Issue Brief \# 380. http://www.epi.org/publication/ceo-paycontinues-to-rise/. Accessed June 9, 2017.

Dudley, Kathryn Marie (1994) The End of the Line: Lost Jobs, New Lives in Post-Industrial America. Chicago: University of Chicago Press.

Fraser, Jill Andresky (2002) White-Collar Sweatshop. New York: W.W. Norton \& Company.

Frazier, Ian (2012) Out of the Bronx: Private equity and the cookie factory. The New Yorker February 6. http://www.newyorker.com/magazine/2012/02/06/out-of-the-bronx. Accessed June 9, 2017.

Freeman, Richard B., Joseph R. Blasi, and Douglas L. Kruse (2010) Introduction. In Shared Capitalism at Work: Employee Ownership, Profit and Gain Sharing, and Broad-Based Stock Options. Douglas L. Kruse, Richard B. Freeman and Joseph R. Blasi eds. Pp. 1-37 Chicago: University of Chicago Press.

Fogarty, Ignatius ed. (2014) 2014 Preqin Global Private Equity Report. New York: Preqin Ltd. Gibson-Graham. J.K (2006) A Postcapitalist Politics. Minneapolis: University of Minnesota Press.

Graeber, David (2009) Direct Action: An Ethnography. Oakland: AK Press.

Graeber, David (2014) Anthropology and the rise of the professional-managerial class. Hau: Journal of Ethnographic Theory 4(3):73-88.

Gusterson, Hugh (1997) Studying Up Revisited. PoLAR 20(1):114-119.

Hart, Keith. (2015) Introduction. In Economy for and Against Democracy.' Keith Hart, ed. Pp. 115. New York: Berghan. 
Heras-Saizaritoria, Iñaki. 2014. "The ties that bind? Exploring the basic principles of workerowned organizations in practice.” Organization 21(5):645-665.

Ho, Karen (2009) Liquidated: An Ethnography of Wall Street. Durham: Duke University Press.

Hochsild, Arlie (1983) The Managed Heart. Berkeley: The University of California Press.

Holland, Dorothy and Naomi Quinn eds (1987) Cultural Models in Language and Thought. Cambridge: Cambridge University Press.

Holland, Dorothy, William S Lachicotte Jr., Debra Skinner, and Carole Cain (2001) Identity and Agency in Cultural Worlds. Cambridge: Harvard University Press.

Holland, Max (1989) When the Machine Stopped: A Cautionary Tale from Industrial America. Cambridge: Harvard Business School Press.

Jackall, Robert (1998) Moral Mazes: The Corporate World of Corporate Managers. Oxford: Oxford University Press.

Krippner, Greta (2011) Capitalizing on Crisis: The Political Origins of the Rise of Finance. Cambridge: Harvard.

Kruse, Douglas L. Richard B. Freeman, and Joseph R. Blasi Eds (2010) Shared Capitalism at Work: Emplyoee Ownership, Profit and gain Sharing, and Broad-Based Stock Options. Chicago: National Bureau of Economic Research.

Lam, Bourree (2016) How Much Wealth and Income Does America's 1 Percent Really Have? The Atlantic March 12. https://www.theatlantic.com/business/archive/2016/03/brookings-1percent/473478/. Accessed June 9, 2017.

Lane, Carrie (2011) A Company of One: Insecurity, Independence, and the New World of WhiteCollar Unemployment. Ithaca: Cornell University Press.

Lave, Jean and Etienne Wenger (1991) Situated Learning: Legitimate Peripheral Participation. Cambridge: Cambridge University Press.

Lave, Jean (2011) Apprenticeship in Critical Ethnographic Practice. Chicago: University of Chicago Press.

Maeckelbergh, Marianne. 2011. "Doing is Believing: Prefiguration as Strategic Practice in the Alterglobalization Movement.” Social Movement Studies 10(1):1-20.

Mahony, Siobhán (2006) Developing Community Software in a Commodity World. In Frontiers of Capitalism: Ethnographic reflections on the New Economy. Melissa S. Fisher and Greg Downey, Eds. Durham: Duke University Press. 
Marcus, George E (1995) Ethnography in/of the World System: The Emergence of Multi-Sited Ethnography. Annual Review of Anthropology 24:95-117.

Marx, Karl (1978) Estranged Labor. In The Marx Engels Reader. New York: Norton pp. 70-81.

Nader, Laura (1972) Up the Anthropologist: Perspectives Gained from Studying Up. U.S. Department of health Education \& Welfare Office of Education. ED065375:1-28.

National Center for Employee Ownership (NCEO) (2015a) Employee Ownership Report. 35(2).

National Center for Employee Ownership (NCEO) (2015b) America's Largest Majority Employee-Owned Companies. Employee Ownership Report 35(4) July-August: 8-9.

Ortner, Sherry B (1984) Theory in Anthropology since the Sixties. Comparative Studies in Society and History 26(1):126-166.

Ortner, Sherry B. (2016) Dark anthropology and its others. Hau: Journal of Ethnographic Theory 6(1):47-73.

Paranque, Bernard. 2014. "Cooperatives — saviours or gravediggers of capitalism? Critical performativity and the John Lewis Partnership." Organization 21(5):604-625.

Piketty, Thomas (2014) Capital in the Twenty-First Century. Arthur Goldhammer trans. Cambridge: Harvard University Press.

Pitluck, Aaron, Fabio Mattioli, and Author. in press. "Finance beyond function: Three causal explanations for financialization." Economic Anthropology.

Reedy, Patrick, Daniel King, Christine Coupland. 2016 “Organizing for Individuation: Alternative Organizing, Politics, and New Idenitites.” Organization Studies 37(11):1553-1573.

Sennett, Richard (1998) The Corrosion of Character: The Personal Consequences of Work in the New Capitalism. New York: W.W. Norton.

Stiglitz, Joseph (2013) The Price of Inequality: How Today's Divided Society Endangers Our Future. New York: Norton.

Tsing, Anna Lownhaupt (2015) The Mushroom at the End of the World. Princeton: Princeton University Press.

Walley, Christine J (2013) Exit Zero: Family and Class in Postindustrial Chicago. Chicago: University of Chicago Press.

West, Paige (2012) From Modern Production to Imagined Primitive: The Social World of Coffee from Papua New Guinea. Durham: Duke University Press. 